Quarterly Journal of Economics and Economic Policy

2014 VOLUME 9 ISSUE 2, June

p-ISSN 1689-765X, e-ISSN 2353-3293

www.economic-policy.pl

Warżała R. (2014), The Impact of Business Cycles on the Foreign Direct Investment Inflows to Poland, "Equilibrium. Quarterly Journal of Economics and Economic Policy", Volume 9, Issue 2, pp. 25-39, DOI: http://dx.doi.org/10.12775/EQUIL.2014.009

Rafał Warżała *

University of Warmia and Mazury in Olsztyn, Poland

\title{
The Impact of Business Cycles on the Foreign Direct Investment Inflows to Poland
}

JEL Classification: $E 32, F 21, F 23, F 44$

Keywords: foreign direct investment, business cycle

\begin{abstract}
The core of this article is to study the impact of the last world economic crisis and world foreign direct investment fluctuations in the same period. The empirical study was based on data published by UNCTAD in annual reports, called World Investment Report. The research concerning the Polish economy was based on data of Polish National Bank.

For measuring the relation between studied phenomena, the analysis of correlation was used, as well as the structure rate and the rate of growth. For the evolution of GDP fluctuations in Poland in the years 1990-2012, both the method of statistical analysis and the descriptive method were used.

In the latest World Investment Report (WIR 2012) one can find the current world financial crisis involved in the drop of foreign direct investment flows. That was characteristic for the Polish economy, too. The main reasons for that are the descending investment capability of corporations, because of poorer profits level and higher costs of bank credits. The important argument for corporation investment slump is that the prospects of world economic growth are unfavourable.
\end{abstract}

(c) Copyright Institute of Economic Research \& Polish Economic Society Branch in Torun Date of submission: March 13, 2013; date of acceptance: December 18, 2013

* Contact: rafal.warzala@uwm.edu.pl, Department of Macroeconomics, University of Warmia and Mazury in Olsztyn, ul. K. Obitza 2, 10-725 Olsztyn, Poland 


\section{Introduction}

Business cycle fluctuations that are inherent in a market economy cover most areas of economic life. In the period of a slowdown in domestic economic indicators, including investment, consumption, production, an important complement to the above mentioned factors can be the inflow of foreign direct investment. However, the analysis of international capital flows in the form of FDI shows that, just as domestic investment, they are subject to cyclical changes. This is evidenced by the recent global economic crisis, which caused a decline in global FDI flows, including the reduction of inflow into the Polish economy. This is caused by the reduction in the ability of companies to invest mainly because of limited access to the financial resources of their own (reduced profits) as well as foreign ones (higher cost of capital loans), and a decrease in the willingness to invest, resulting from the negative economic growth forecast.

In these circumstances, in order to stimulate further inflows of FDI into the Polish economy, it is important to carry out an appropriate policy of attracting foreign direct investment. This is especially crucial, because Poland must compete for FDI, with other Central and Eastern Europe countries, which often creates more profitable conditions for investment.

A characteristic feature of the world economy is deepening its internationalization process and the transition to a higher stage of globalization. This means an increase in the intensity of economic links among countries, regions and companies (Rymarczyk, 2004, p. 7). The existence of numerous and - as indicated by J. Rymarczyk - often very strong relationships in the world makes it easy to move all economic "turbulences" from one country to another.

The result of internationalization economic fluctuations is also spreading its effects in the world's real economy. One of the most important negative effect of this is to stop the processes of investment in the economy. It resulted from the loss of financial liquidity of enterprises, because of increasing commitments and the need to repay debt in the face of declining market demand. The result of the current financial problems of companies is freezing strategic decisions, such as for the implementation of planned investments. It can therefore be concluded that international capital flows in the form of foreign direct investment can be a transmission channel of cyclical fluctuations.

The last economic crisis began in the United States and, like the great economic crisis of the late 20 s and 30 s the twentieth century, was the consequence of bank's errors. It quickly moved first into the United States real economy, and later caused a lot of problems in the functioning of various countries in the world (Bednarczyk et al., 2009, p. 4). This situation also had 
a negative impact on the scale of total world foreign direct investment (FDI). Many international companies have been forced to repay the debt and hold investment processes. This change marked the emergence of a new trend in which capital flows have been severely reduced by the global financial crisis.

\section{Purpose and methodology of the research}

The purpose of this article is to evaluate the relationship between capital inflows in the form of foreign direct investment, and the economic situation expressed by the GDP fluctuations. The time horizon of the analysis covers the period of economic transformation in Poland (1990-2012). The empirical study is based on data published by UNCTAD in annual reports, called World Investment Report. The research concerning the Polish economy, was based on the data of the Polish National Bank.

The assessment of the relationship between foreign direct investment inflows into Polish, and the volatility of GDP, there is the analysis of causality. It was supported by the use of simple statistical measures to assess correlation of the studied phenomena, such as the structure rate and the rate of growth. For the evolution of GDP fluctuations in Poland in the years 19902012, I used the method of description and analysis. It is based on an accurate description of the events which are the subject of research in statistical, dynamic and geographical aspect. Analysis of the data also required deductive and inductive approaches, which allowed to draw the appropriate final conclusions.

Accomplishment of the objectives involved the use of comparison method. Assessment of the impact of GDP on capital inflows in the form of FDI to Poland was necessary to notice changes in this respect. The basis of a comparative analysis of correlation was similarity to the EU. The results were presented in graphical form.

\section{International capital flows in the form of FDI and the state of the global economy ${ }^{1}$}

The period from the last decade of the XX. century was characterized by a significant increase in the dynamics of global capital flows. This applies to

${ }^{1}$ Prepared on the basis of publication: World Investment Report, UNCTAD, New York and Geneva, from the years of 2000-2012, www.unctad.org /en /PublicationsLibrary. 
both portfolio investment and direct investment. The acceleration of international capital flows resulted from the growing diversity of economic growth in different regions of the world. Another inducement was the progress in the liberalization of international capital flows (Karaszewski, 2004, p. 88).

In the period 1991-2000 the growth rate of FDI flows exceeded global GDP growth. As shown in Table 1, the share of FDI flows to GDP has increased significantly during the period from 0,68 percent in 1991 to 4,31 percent in 2000. In the years 1998-1999 global FDI flows reached an annual increase in scale of 42 percent (1998) and 57 percent (1999). In 2000, the growth rate of world FDI flows moderated somewhat and reached 29 percent, but was still significantly higher than the corresponding changes in the value of world GDP.

Table 1. The global GDP and FDI flows and stocks in the years of 1990-2013 (U.S. billion dollars, current prices)

\begin{tabular}{|c|c|c|c|c|c|}
\hline PERIOD & GDP & $\begin{array}{c}\text { FDI } \\
\text { STOCKS }\end{array}$ & $\begin{array}{c}\text { SHARE } \\
\text { IN GDP }\end{array}$ & $\begin{array}{c}\text { FDI } \\
\text { FLOWS }\end{array}$ & $\begin{array}{c}\text { SHARE } \\
\text { IN GDP }\end{array}$ \\
\hline 1990 & 22185,3 & 210,3 & 0,9 & 210,3 & 1,0 \\
1991 & 23261,5 & 369,3 & 1,6 & 158,9 & 0,7 \\
1992 & 24344,0 & 545,1 & 2,2 & 175,8 & 0,7 \\
1993 & 24984,4 & 764,5 & 3,1 & 219,4 & 0,9 \\
1994 & 26808,5 & 1020,5 & 3,8 & 256,0 & 1,0 \\
1995 & 29799,1 & 1351,6 & 4,5 & 331,1 & 1,1 \\
1996 & 30521,0 & 1737,7 & 5,7 & 386,1 & 1,3 \\
1997 & 30388,4 & 2219,6 & 7,3 & 481,9 & 1,6 \\
1998 & 30171,6 & 2905,7 & 9,6 & 686,0 & 2,3 \\
1999 & 31348,2 & 3984,8 & 12,7 & 1079,1 & 3,4 \\
2000 & 32306,2 & 5377,7 & 16,6 & 1393,0 & 4,3 \\
2001 & 32099,7 & 6201,5 & 19,3 & 823,8 & 2,6 \\
2002 & 33354,7 & 6852,7 & 20,5 & 651,2 & 2,0 \\
2003 & 37493,9 & 7410,6 & 19,8 & 557,9 & 1,5 \\
2004 & 42177,5 & 8121,4 & 19,3 & 710,8 & 1,7 \\
2005 & 45615,6 & 9080,0 & 19,9 & 958,7 & 2,1 \\
2006 & 49375,2 & 10543,4 & 21,4 & 1463,4 & 3,0 \\
2007 & 55718,2 & 12518,9 & 22,5 & 1975,5 & 3,6 \\
\hline
\end{tabular}


Table 1 continued

\begin{tabular}{|c|c|c|c|c|c|}
\hline PERIOD & GDP & $\begin{array}{c}\text { FDI } \\
\text { STOCKS }\end{array}$ & $\begin{array}{c}\text { SHARE } \\
\text { IN GDP }\end{array}$ & $\begin{array}{c}\text { FDI } \\
\text { FLOWS }\end{array}$ & $\begin{array}{c}\text { SHARE } \\
\text { IN GDP }\end{array}$ \\
\hline 2008 & 61221,6 & 14309,6 & 23,4 & 1790,7 & 2,9 \\
2009 & 57846,2 & 15507,5 & 26,8 & 1197,8 & 2,1 \\
2010 & 63179,6 & 16816,5 & 26,6 & 1309,0 & 2,1 \\
2011 & 69899,2 & 18340,9 & 26,2 & 1524,4 & 2,2 \\
2012 & 71277,4 & 19940,9 & 28,0 & 1600,0 & 2,2 \\
2013 & 74148,6 & 21740,9 & 29,3 & $1800,0 *$ & 2,4 \\
\hline
\end{tabular}

* UNCTAD's forecast

Sources: own research based on: World Investment Report 2012... (2012, pp. 169, 173); World Investment Report 2011... (2011, pp. 187, 191); World Investment Report 2010... (2010, pp. 188, 192); World Investment Report 2009...,(2009, pp. 180, 189); World Investment Report 2008... (2008, pp. 182, 189); World Investment Report 2007... (2007, pp. 180, 189); World Investment Report 2006... (2006, pp. 186, 198); World Investment Report 2005... (2005, pp. 183, 189); World Investment Report 2004... (2004, pp. 187, 201); World Investment Report 2003.. (2003, pp. 249, 257); World Investment Report 2002... (2002, pp. 244, 257; World Investment Report 2001... (2001, pp. 245, 252); World Investment Report 2000..., (2000, p. 284, 292).

Global GDP growth in the 90s also belonged to the highest in the last 50 years. It was the result of a dynamic development of the world's largest economy - the United States. The record growth the economies of SouthEast Asia, and Central and Eastern Europe was also of great importance. These regions were the main areas of penetration of foreign capital in the form of FDI.

The twenty-first century began with the crisis in the global economy. It was started in the U.S. economy, and became known as "dot-com crisis", because it concerned the sharp declines in stock market concerning the largest American companies in the IT sector. The unfounded belief in resistance to the crisis by the IT sector resulted in the separation of the value of these companies equity from their real growth rate and from the ability to generate profits. Finally, after the dynamic increases, next came the high drop of their prices in the stock market.

The second event that contributed to the coming recession in the U.S., were terrorist attacks in the U.S. in 2001. Despite the fact that they had no direct impact on the state of the United States economy, it implicitly perpetuated in 2000 the financial crisis in the United States, as well as in the other developed economies of the world. 
Table 2. The GDP value and the stocks and flows of FDI in Poland and the EU in the years 1990-2011 (current prices)

\begin{tabular}{|c|c|c|c|c|c|c|c|}
\hline Period & $\begin{array}{c}\text { Poland } \\
\text { FDI } \\
\text { (in US } \\
\text { million } \\
\text { dollars) }\end{array}$ & $\begin{array}{c}\text { EU FDI } \\
\text { (in US } \\
\text { million } \\
\text { dollars) }\end{array}$ & $\begin{array}{c}\text { Poland } \\
\text { GDP } \\
\text { (in US } \\
\text { million } \\
\text { dollars) }\end{array}$ & $\begin{array}{c}\text { EU GDP } \\
\text { (in US } \\
\text { billion } \\
\text { dollars) }\end{array}$ & $\begin{array}{c}\text { col. 2/ } \\
\text { col. 4 } \\
\text { (in \%) }\end{array}$ & $\begin{array}{c}\text { col. 3/ } \\
\text { col. 5 } \\
\text { (in \%) }\end{array}$ & $\begin{array}{c}\text { col. 2/ } \\
\text { col. 3 } \\
\text { (in \%) }\end{array}$ \\
\hline 1990 & 89 & 97387 & 64500 & 6974,5 & 0,1 & 1,4 & 0,1 \\
1991 & 291 & 78777 & 83600 & 7442,5 & 0,3 & 1,1 & 0,4 \\
1992 & 678 & 83794 & 92300 & 7741,5 & 0,7 & 1,1 & 0,8 \\
1993 & 1715 & 76754 & 94000 & 7767,5 & 1,8 & 1,0 & 2,2 \\
1994 & 1875 & 76866 & 108400 & 8138 & 1,7 & 0,9 & 2,4 \\
1995 & 3659 & 113480 & 139100 & 9149,4 & 2,6 & 1,2 & 3,2 \\
1996 & 4498 & 110376 & 156700 & 9616,1 & 2,9 & 1,1 & 4,1 \\
1997 & 4908 & 127888 & 157200 & 10149,1 & 3,1 & 1,3 & 3,8 \\
1998 & 6364 & 249931 & 172900 & 10627,5 & 3,7 & 2,4 & 2,5 \\
1999 & 7270 & 479372 & 167800 & 11165,7 & 4,3 & 4,3 & 1,5 \\
2000 & 9341 & 671417 & 171300 & 11961,3 & 5,5 & 5,6 & 1,4 \\
2001 & 5713 & 357441 & 190400 & 12459,2 & 3,0 & 2,9 & 1,6 \\
2002 & 4131 & 420433 & 198200 & 12915,5 & 2,1 & 3,3 & 1,0 \\
2003 & 4589 & 253728 & 216800 & 13135,2 & 2,1 & 1,9 & 1,8 \\
2004 & 12890 & 204245 & 252800 & 13787,8 & 5,1 & 1,5 & 6,3 \\
2005 & 10363 & 498400 & 303900 & 14393,6 & 3,4 & 3,5 & 2,1 \\
2006 & 19603 & 585030 & 341700 & 15211,3 & 5,7 & 3,8 & 3,4 \\
2007 & 23561 & 853966 & 425300 & 16127,8 & 5,5 & 5,3 & 2,8 \\
2008 & 14839 & 542242 & 529400 & 16214,9 & 2,8 & 3,3 & 2,7 \\
2009 & 12392 & 356631 & 430900 & 15277,6 & 2,9 & 2,3 & 3,5 \\
2010 & 8858 & 318277 & 469800 & 15964 & 1,9 & 2,0 & 2,8 \\
2011 & 15139 & 420715 & 514500 & 16435,9 & 2,9 & 2,6 & 3,6 \\
\hline
\end{tabular}

Source: as in Table 1.

The negative effect of rapid spread of cyclical impulses in the world economy as a result of the liberalization of capital flows also revealed itself during the recent crisis, which started in 2007. The immediate cause of the recent slump in the U.S. economy was the market situation of the subprime mortgage. The increase in the share of such assets in the portfolios of the 
banks did not have a negative impact on their financial situation as long as the real estate prices were rising. The collapse in house prices in the United States resulted in the bankruptcy of financial institutions, as well as the transfer of part of the cost of rescuing the parent companies to subsidiaries located in third countries, which did not participate directly in such risky ventures. A similar mechanism for the spread of the crisis on the international scale, took place in in the United Kingdom and Spain banking system.

\section{Determinants of FDI in the Polish economy²}

The inflow of capital in the form of FDI into the Polish economy in the 90s was characterized by a high annual growth rate for some reasons. The first one is called statistical base effect. It consists of low-value basis for the calculation of FDI annual growth rate. This is due to the fact that by 1990 the scale of these investments was negligible. The second reason for the high growth rate of FDI inflows into Poland in the 90s was the implementation of reforms during the economic transformation. This was the matter of law changes that aimed at gradual liberalization of capital flows in FDI form in Poland. This was reflected in the increasing growth of FDI inflows to Poland.

The process directly related to the first stage of economic transition, as well as the attraction of foreign capital in the form of FDI, was the privatization of state-owned enterprises. The privatization was aimed on the one hand at limiting the public sector area and the number of state owned enterprises, and on the other hand at adjusting the scale and structure of production to market demand. In many cases it required attracting a so-called strategic investor who had the necessary technological knowledge and ensured including the acquired enterprise into its own long-term development perspectives. Therefore, in the 90s in Poland, the main form of FDI, was the purchase of privatized enterprises in the process carried out by the Ministry of Treasury (Calski, 2003, p. 212).

${ }^{2}$ Prepared on the basis of publication: World Investment Report, UNCTAD, New York and Geneva, from the years of 2000-2012, www.unctad.org /en /PublicationsLibrary. 
Figure 1. The share of FDI in the Polish and EU GDP and the share of FDI flows in Poland in the total value of FDI flows in the EU in the period 1990-2011

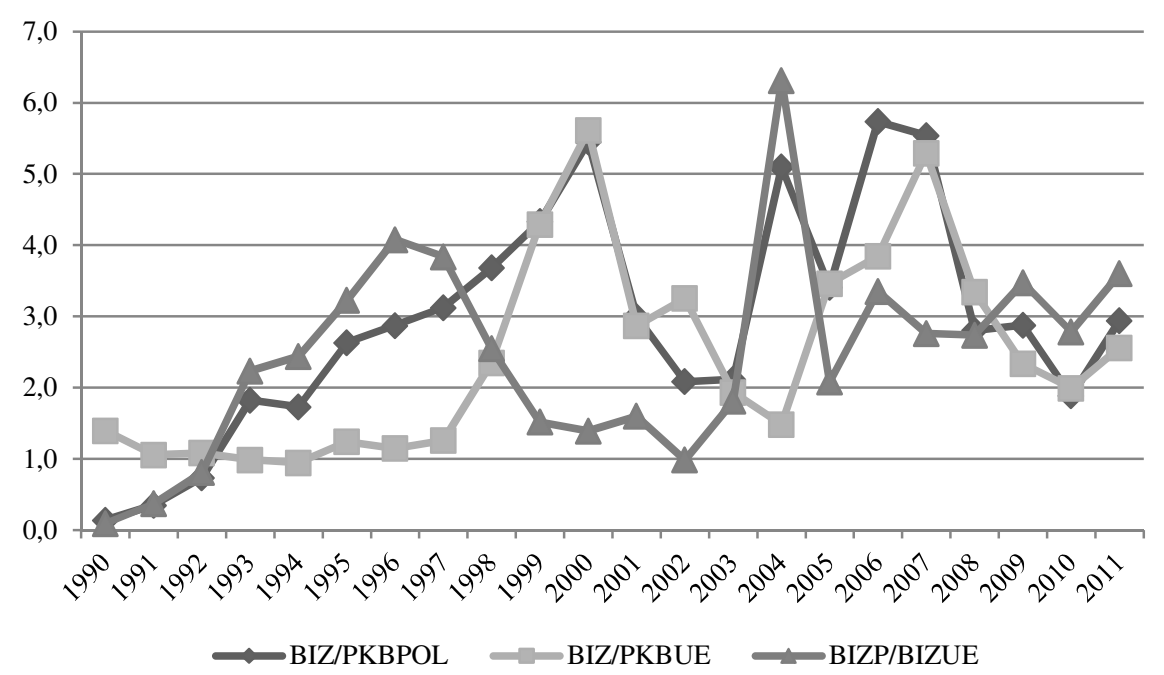

Source: own research, based on: World Investment Report 2012... (2012, pp. 169, 173).

The last of the events that had a significant impact on the value of annual inflows of FDI to Poland, was the year of Polish accession to the EU. Since 2004, the inflow of FDI to our country has regularly exceed \$ 10 billion. The exception in this period was 2010, when foreign investment was reduced to less than $\$ 9$ billion.

As shown in Table 2, the share of FDI inflows to Poland, in relation to GDP, was differential. It ranged from $0,1 \%$ in the first year of transition, to $5,7 \%$ in 2006 , when the country attracted FDI worth over U.S. \$ 19,6 billion. Similar shares FDI in GDP took place in 2000 and 2007, so during the final stages of the growth period preceding the crisis. The cumulative value of FDI in Poland by the end of 2011, accounted for over 33\% of GDP value. Growing from year to year, the share of FDI in GDP in Poland indicates that the average growth rate of FDI inflow is higher, compared with GDP growth rate. 


\section{FDI inflows to Poland in comparison to the $\mathrm{EU}$}

Regarding the involvement of foreign capital in the form of FDI in the Polish economy to the corresponding share of FDI in GDP of all EU countries, the diversity of commitment that forms of capital in the EU can be seen. In 1990-1994 and 2005-2011 the intensity of the involvement of FDI in the economies of the EU was on average higher than the corresponding ratio for the Polish economy, and in the period 1995-2004, the intensity was lower. Apart from the first period 1990-1994, when the inflow of foreign capital into Poland was in its early stages, the next two periods have their own grounds. In the period 1995-2004, which was the time of greatest growth in FDI in Poland, the interest of foreign investors in the countries of Central and Eastern Europe was high due to the processes discussed above, like the liberalization of law, privatization, and lower labor costs in relation to the EU members. These arguments, combined with relatively large and absorbent market, accounted for a reorientation of FDI flow directions from the domestic area of the EU, to the countries associated with the EU.

The next period of 2005-2011, begins with Polish and other nine Central and Eastern Europe countries' EU membership. During this period, in the common economic area, further intensification of FDI inflows to the new EU members took place. In addition, in 2007 the last enlargement of the EU took place, in which two medium-sized countries (Romania and Bulgaria) were accessed. Both of these countries characterized by a lower GDP level in comparison to Poland, and also lower labor costs. Despite high and increasing absolute values of FDI inflows to Poland, the failure of our country in the battle for several major automotive investments with the Czech Republic and Slovakia, caused that the scale of FDI, in relation to GDP was lower than in the remaining areas of the EU. An important factor in this period was also the difference in the dynamics of GDP growth, which refers to the value of FDI. In the Polish case, it was double the average growth rate across the EU.

The decline in economic activity associated with the global financial crisis has caused not only a decrease in the value of worldwide FDI flows. The deterioration in financial standing, higher requirements for companies to obtain bank loans and negative assessment of prospects for development, caused the multinational companies reduced investment projects in the form of greenfield. There was also a decline in the value of brownfield investments, consisting primarily on acquiring shares in existing entities. 
There are several reasons for the decline of foreign direct investments in the period 2008-2009. These were (Assessing the Impact ..., 2009, pp. 7-9):

- decline in the value of cross-border mergers and acquisitions - the main reason for reduction of FDI in the world. There was the five-year period of very rapid growth, reaching $39 \%$ in 2008 and $66 \%$ in 2009 ,

- decrease in the number of so-called mega deals - in 2008 the number dropped by $21 \%$ and the value by $31 \%$,

- limited internal funding (drop in profits) and the use of external sources of capital (the requirements for obtaining credit are more difficult to fulfill),

- financial factors significantly reduced the ability of multinational corporations to invest in both the home country and abroad,

- poor market prospects, especially in developed countries,

- aversion to risk in times of crisis, lower propensity to invest, a high level of perceived risk and uncertainty,

- change in strategy - falling profits and financial pressures have led to a decline in reinvested earnings and changes in the loans (with a branch to the central foreign corporations),

- number of greenfield investments - in 2008, still growing, but in 2009 their value fell by $23 \%$,

- decline in sales - experienced by large companies in many sectors (initially in financial services, then the other).

During the economic and financial crisis, the global value of greenfield investment projects fell in 2011 by $45 \%$ compared to a record in 2008. At the same time, the share of EU countries in the total value of greenfield investment projects in the world declined by $50 \%$. In the analyzed period, one out of five dollars spent on this type of investment was invested in the EU area. Although the decline affected all EU countries, it was different in each of the countries surveyed.

In Poland, greenfield FDI relative to the corresponding value in the world ranged from 1,6 percentage points in 2006 to 1,4 percentage points in 2011, while in the period of 2007-2008, which is the pre-crisis period, it was 2,2 percentage points. In the Czech Republic, this proportion ranged from 0,8 to 0,5 percentage points, so it was more stable than the changes in Poland. In addition, the half the size of Polish participation of the Czech Republic, resulted in twice its value in relative terms, meaning per capita. In Hungary, with a similar population to the Czech Republic, this share ranged from 0,9 percentage points in 2006 to 0,3 percentage points in 2011. It means more fluctuations in relative terms, as well as in comparison to the Czech Republic, and a decline in the total world greenfield investment in the last researched year. It is a consequence of deterioration of the economic position of Hungary in the last two years (high public debt and inflation). Against this 
background of the countries discussed, in Slovakia the share of greenfield projects ranged from 1,2 percentage points in 2006, to a 0,6 percentage points in 2011. However, it should be noted that in this comparison it is the smallest country in terms of population, which at the same time, noted twice the value of Hungary's participation in greenfield investments. Compared to the Czech Republic, the share was also higher in relative terms.

Table 3. Value and share of greenfield investment in selected regions of the world in the years 2006-2011 (U.S. \$ billion)

\begin{tabular}{|l|c|c|c|c|c|c|c|c|c|c|c|c|}
\hline \multirow{2}{*}{ Area } & \multicolumn{2}{|c|}{2006} & \multicolumn{2}{c|}{$\mathbf{2 0 0 7}$} & \multicolumn{2}{c|}{$\mathbf{2 0 0 8}$} & \multicolumn{2}{c|}{$\mathbf{2 0 0 9}$} & \multicolumn{2}{|c|}{$\mathbf{2 0 1 0}$} & \multicolumn{2}{|c|}{$\mathbf{2 0 1 1}$} \\
\cline { 2 - 12 } & $\mathbf{V}$ & $\mathbf{S}$ & $\mathbf{V}$ & $\mathbf{S}$ & $\mathbf{V}$ & $\mathbf{S}$ & $\mathbf{V}$ & $\mathbf{S}$ & $\mathbf{V}$ & $\mathbf{S}$ & $\mathbf{V}$ & S \\
\hline World & 989,6 & 100 & 1015,7 & 100 & 1634,4 & 100 & 1051,6 & 100 & 904,6 & 100 & 904,3 & 100 \\
EU & 228,0 & 23,0 & 229,3 & 22,5 & 332,3 & 20,3 & 197,2 & 18,8 & 162,5 & 18,0 & 167,3 & 18,5 \\
PL & 15,6 & 1,6 & 22,8 & 2,2 & 35,2 & 2,2 & 14,5 & 1,4 & 11,4 & 1,3 & 12,6 & 1,4 \\
CZ & 7,7 & 0,8 & 7,5 & 0,7 & 5,7 & 0,4 & 4,6 & 0,4 & 7,7 & 0,9 & 4,9 & 0,5 \\
SK & 1,1 & 0,2 & 5,5 & 0,5 & 3,3 & 0,2 & 5,4 & 0,5 & 4,2 & 0,5 & 5,7 & 0,6 \\
HU & 8,8 & 0,9 & 9,5 & 0,9 & 9,0 & 0,6 & 4,7 & 0,4 & 7,5 & 0,8 & 3,2 & 0,3 \\
\hline
\end{tabular}

$\mathrm{V}$ - value; $\mathrm{S}$ - share

Source: own research, based on: World Investment Report. Towards... (2012, p. 189).

The second important component of capital flows in the form of FDI, are brownfield investments, which rely on the purchase of all or a part of shares in existing enterprises, in order to gain control over a specific entity. Although, paradoxically, the crisis should encourage restructuring processes and the search for new, more effective solutions, in 2007-2008, fewer and fewer transnational corporations engaged in the development of new projects. This was true both for investments seeking new markets, as well as targeted investments in new resources. A decrease in new investment project mainly concerned developed countries. Among the reasons for this, in addition to the previously mentioned financial and credit constraints, is the higher risk of such ventures and poor perspectives for the economic growth in the world.

The loss of financial liquidity by many transnational corporations resulted in compensate for the losses incurred in some countries, by profits gain in countries that managed to avoid bankruptcy on a large scale. In 2007-2009, instead of reinvestment of profits, there have been significant divestments, related with the withdrawal of capital, and with the restructuring and closing the least profitable subsidiaries and affiliates. 
In the years 2006-2011 the value of global mergers and acquisitions decreased by 16\%. In 2007 - the record year of brownfield investment, the value of such capital flows was almost twice higher than in 2011. In the EU brownfield investments decreased by $67 \%$ compared to 2007 and in relation to 2006 - the beginning of the researched period, the decrease was $48 \%$.

Table 4. Value and share of brownfield investment in selected regions of the world in the years 2006-2011 (U.S. \$ billion)

\begin{tabular}{|l|c|c|c|c|c|c|c|c|c|c|c|c|}
\hline \multirow{2}{*}{ Area } & \multicolumn{2}{|c|}{2006} & \multicolumn{2}{c|}{2007} & \multicolumn{2}{c|}{$\mathbf{2 0 0 8}$} & \multicolumn{2}{c|}{$\mathbf{2 0 0 9}$} & \multicolumn{2}{c|}{$\mathbf{2 0 1 0}$} & \multicolumn{2}{c|}{$\mathbf{2 0 1 1}$} \\
\cline { 2 - 13 } & $\mathbf{V}$ & $\mathbf{S}$ & $\mathbf{V}$ & $\mathbf{S}$ & $\mathbf{V}$ & $\mathbf{S}$ & $\mathbf{V}$ & $\mathbf{S}$ & $\mathbf{V}$ & S & V & S \\
\hline World & 625,3 & 100 & 1022,7 & 100 & 706,5 & 100 & 249,7 & 100 & 344,0 & 100 & 525,9 & 100 \\
EU & 333,3 & 53,3 & 527,7 & 51,6 & 251,2 & 35,5 & 116,2 & 46,5 & 116,0 & 33,7 & 172,3 & 32,7 \\
PL & 0,8 & 0,1 & 0,73 & 0,07 & 0,97 & 0,14 & 0,77 & 0,31 & 1,06 & 0,31 & 10,0 & 1,9 \\
CZ & 1,1 & 0,2 & 0,1 & 0,01 & 5,17 & 0,73 & 2,67 & 1,1 & 0,46 & 0,13 & 0,725 & 0,13 \\
SK & 0,2 & 0,03 & 0,050 & 0 & 0,136 & 0,02 & 0,013 & 0 & - & 0 & 0 & 0 \\
HU & 2,3 & 0,4 & 0,72 & 0,07 & 1,559 & 0,22 & 1,85 & 0,7 & 0,21 & 0,06 & 1,71 & 0,32 \\
\hline
\end{tabular}

$\mathrm{V}$ - value; $\mathrm{S}$ - share

Source: own research, based on: World Investment Report. Towards... (2012, p. 189).

The share of EU in the total value of mergers and acquisitions in the world in 2006 was 53,3\%, and decreased by 20 percentage points in 2011 . Against this background, the share of Poland in such projects in the world is marginal. However, in 2011 there was a significant increase in this area, to more than $\$ 10$ billion, after a few years during which the value of mergers and acquisitions had not exceeded $\$ 1$ billion. This was due to a few large acquisitions in the banking, telecommunications and energy sector. For the other countries that are the subject of analysis, the participation in the world's total value of mergers and acquisitions does not exceed 1,1 percentage points.

Poland as the host country of FDI location, is gradually turning into a net foreign investor, seeking lower labor costs, as well making use of acquired know-how in other developing countries. This is the result of a learning process, imported technology, purchased licenses and gradually improved capacity for innovation. 
Table 5. The value of Polish foreign direct investment in the period 2000-2011 (in million EUR)

\begin{tabular}{|c|c|c|c|c|c|}
\hline Year & $\begin{array}{c}\text { Share } \\
\text { capital }\end{array}$ & $\begin{array}{c}\text { Reinvested } \\
\text { earnings }\end{array}$ & $\begin{array}{c}\text { Capital } \\
\text { in transition }\end{array}$ & $\begin{array}{c}\text { Other } \\
\text { capital }\end{array}$ & Total \\
\hline 2000 & 122 & -13 & - & -91 & 18 \\
2001 & -52 & 10 & - & -55 & -97 \\
2002 & 275 & -77 & - & 30 & 228 \\
2003 & 92 & -9 & - & 186 & 269 \\
2004 & 444 & 20 & - & 293 & 757 \\
2005 & 2257 & 44 & - & 491 & 2792 \\
2006 & 6098 & 464 & 3030 & 575 & 7137 \\
2007 & 2945 & -63 & 1322 & 1138 & 4020 \\
2008 & 1927 & 156 & 392 & 989 & 3072 \\
2009 & 3612 & -997 & 1403 & 720 & 3335 \\
2010 & 627 & 230 & 1355 & 4598 & 5455 \\
2011 & 3700 & 262 & 1468 & 1181 & 5143 \\
\hline
\end{tabular}

Source: http://www.nbp.pl/publikacje/ib_raporty/raport_ib_2011.pdf (12.03.2013).

In the years 2000-2011 the total amount due under Polish direct investment abroad reached to EUR 38,4 billion ${ }^{3}$. Compared to 2010, there was an increase of EUR 5,1 billion. The increase in accounts receivable resulted both from the increase in the value of equity capital and reinvested earnings, and the increase in the value of the remaining capital.

In 2011, the total amount of net capital outflow due to Polish direct investment abroad amounted to EUR 5,143 million, compared with 2010 decrease of EUR 312 million (6\%). The main reason for the decline of direct investment was a significant reduction in the level of turnover in other capital. The value of the remaining equity - widening Polish direct investment abroad amounted to EUR 1,181 million and was EUR 3,417 million lower than the previous year. The highest total value of Polish investments abroad took place in the years 2006, 2007, 2009 and 2011.

In Table 5 the structure of the Polish direct investment abroad was presented. It can be noted that the structure of these investments during the researched period is irregular. The most important are the investments whose purpose is the purchase of shares by direct investment companies. The highest value of the purchased shares occurred in 2006 and 2010 and 2011. The highest value of reinvested earnings was recorded in 2006 and in 2010-2011. In the years 2000, 2002, 2007 and 2009, the value of reinvested earnings was

\footnotetext{
${ }^{3}$ Source: http://www.nbp.pl/publikacje/ib_raporty/raport_ib_2011.pdf.
} 
negative, which meant that in the face of rising risks associated with the crisis, they were transferred to Poland. Against the background of decreasing value of reinvested profits, in the years 2007, 2010 and 2011, one can observe an increase in the value of other investments. They are mainly in the form of credits and loans granted to direct investment enterprises by parent companies.

In NBP reports since 2006 there is one more item related to flows of capital in the form of FDI. It is called capital in transition. It is apparent in official statistics, but has no real economic effect. These are funds that are directed from international corporations to our country in order to get through a company registered in Poland. The main purpose of such activity is to reduce their tax burden.

\section{Conclusions}

Changes in the global economy are also reflected in international capital flows in the form of FDI. When multinational corporations have subsidiaries located in many countries, the deterioration of the economic situation in one country affects the economic decisions of the parent company concerned with transfer of profits. Globally, there has been a decline in the share of FDI located in developed countries, due to financial crisis. In the forms of FDI the greater decrease due to the crisis occurred in greenfield investments. In the case of Poland, still, despite the crisis, we are the leader in terms of the absolute value of capital inflows in the form of FDI. However, in relative terms (value per capita), our country occupies a worse place.

Although we have not managed yet to reach the inward FDI from the period before the crisis, the outlook for 2013 is optimistic. If they are investing in a competitive business, it can be hoped that they will contribute to accelerate the return of the Polish economy to the path of high growth rate.

\section{References}

Assessing the impact of the current financial and economic crisis on global FDI flows (2009), UNCTAD, New York and Geneva.

Bednarczyk J.L., Bukowski S.I., Misala J. (2009), Contemporary economic crisis. The causes, course and consequences, CeDeWu, Warsaw.

Calski P. (2003), Participation of foreign investors in the privatization of the Polish enterprises in the period 1990-2002 [in:] Karaszewski W. (ed.), Foreign Direct Investment in Poland, Nicolaus Copernicus University, Torun.

Drozdowicz-Bieć M. (2012), Cycles and economic indicators, Poltext, Warsaw. 
Karaszewski W. (2004), Foreign Direct Investment. Poland against the world, Dom Organizatora, Torun.

Rymarczyk J. (2004), Internationalization and globalization of the company, PWE, Warsaw.

World Investment Report 2012. Towards a new generation of investment policies (2012), UNCTAD, New York and Geneva.

World Investment Report 2011. Non-equity modes of international production and development (2011), UNCTAD, New York and Geneva.

World Investment Report 2010. Investing in a low-carbon economy (2010), UNCTAD, New York and Geneva.

World Investment Report 2009. Transnational Corporations, Agricultural Production and Development (2009), UNCTAD, New York and Geneva.

World Investment Report 2008. Transnational Corporations, and the Infrastructure Challenge (2008), UNCTAD, New York and Geneva.

World Investment Report 2007. Transnational Corporations, Extractive Industries and development (2007), UNCTAD, New York and Geneva.

World Investment Report 2006. FDI from Developing and Transition Economies: Implications for Development (2006), UNCTAD, New York and Geneva.

World Investment Report 2005. Transnational Corporations and the Internationalization of $R \& D$ (2005), UNCTAD, New York and Geneva.

World Investment Report 2004. The Shift Towards Services (2004), UNCTAD, New York and Geneva.

World Investment Report 2003. FDI Policies for Development: National and International Perspectives (2003), UNCTAD, New York and Geneva.

World Investment Report 2002. Transnational Corporations and Export Competitiveness (2002), UNCTAD, New York and Geneva.

World Investment Report 2001. Promoting linkages (2001), UNCTAD, New York and Geneva.

World Investment Report 2000. Cross-border Mergers and Acquisitions and Development (2000), UNCTAD, New York and Geneva.

www.nbp.pl/publikacje/ib_raporty/raport_ib_2011.pdf (14.03.2013). 